\title{
Modulation of Adhesion Proteins Integrin $\beta 1$ and FAK, and Cytoskeletal Protein Actin by Spermine in MCF-7 Cells
}

\author{
Hye Jin Jee ${ }^{\dagger}$ and Byeong Gee Kim* \\ Department of Biological Sciences, College of Natural Sciences Pusan National University, Busan 609-735, Korea
}

Received November 7, 2011 /Revised December 13, 2011 /Accepted December 19, 2011

\begin{abstract}
Polyamines are essential for cell growth and differentiation; however their precise roles are unclear yet. In the present study, the cytotoxic effect of spermine (spm) on MCF-7 cells was investigated. In the MTT assay of MCF-7 cells treated with spm, cell viability was significantly decreased in a time-and dose-dependent manner. Cell viability measurement was confirmed by trypan blue staining. FACS analysis shows that sub-G1 was increased in a time-and dose-dependent manner too. When the cells were treated with spm, cells started to show morphological changes within $2 \mathrm{hrs}$. The expression of adhesion proteins (FAK and integrin $\beta 1$ ), and cytoskeletal protein (actin) was checked by Western blotting analysis. Integrin $\beta 1$ levels were slightly decreased, and FAK and actin levels were rapidly decreased with spm treatment. In confocal laser scanning microscopy, the distribution of actin did not change but the expression decreased in a dose-dependent manner with spm treatment. FAK was evenly distributed under the plasma membrane in the untreated control. However, at $10 \mu \mathrm{M} \mathrm{spm} \mathrm{FAK}$ seemed to move toward the cell nucleus. Integrin $\beta 1$, which was mainly found in the focal point of the plasma membrane in the untreated control, dispersed through the entire plasma membrane in spm treatment. The present results indicate that cytotoxic effects of spm are triggered by the disruption of adhesion proteins and cytoskeletal protein.
\end{abstract}

Key words : Actin, ECM, FAK, Integrin, spermine

\section{Introduction}

Polyamines such as putrescine (put), spermidine (spd), and spermine (spm) are small, flexible molecules, which bind to nucleic acids and proteins and thus affect their conformation and biological activity [25]. Polyamines are important multifunctional cellular components and are considered mediators of cell growth and division. Recently, polyamines have also been known to be implicated in cell death. It appears that polyamines are bivalent regulators of cellular functions, promoting proliferation or cell death depending on the cell type and on environmental signals [12,18]. Among polyamines, spm was most effective in inhibiting cancer cell growth. The cytotoxicity of spm has been suggested by the production of $\mathrm{H}_{2} \mathrm{O}_{2}$ and aldehyde(s) from spm in the presence of amine oxidase [1,2].

Polyamines are also essential for the normal attachment of cells to the extracellular matrix (ECM), which explains

\footnotetext{
*Corresponding author

Tel : +82-51-510-2286, Fax : +82-51-581-2962

E-mail : bgkim@pnu.edu

† Current address

Department of Biochemistry, College of Medicine, Dong-A University, Busan, Korea
}

at least some of the reliance of cell migration and the organization of the cytoskeleton on normal polyamine levels [22]. The migration of cells depends on their ability to make and break attachments to the ECM. The ECM controls cells through signals via a family of cell surface receptors called integrins [10]. The malignancy of a tumor is associated with its ability to undergo migration and metastasis. Metastases form after a series of sequential, interlinked steps involving a variety of adhesive interactions between cancer cells and host tissues [7]. The mechanism that plays a role in the cytotoxic properties of polyamine may be related to the down-regulation of integrin-associated signaling. Integrin family proteins are receptors that connect cells to the ECM. Integrins function as heterodimeric transmembrane cell surface receptors consisting of $\alpha$ - and $\beta$ - subunits that bind several ECM proteins such as collagen, fibronectin, and laminin at the extracellular domain [11]. Integrin-associated signaling factors have been demonstrated to directly regulate the apoptotic machinery, as well as invasion. The apoptotic mechanism associated with loss of attachment to the ECM is called anoikis, which is also controlled by integrin mediated signaling in cooperation with the cell cycle regulators and pro-apoptotic proteins [9]. Among the integrin family members, integrin $\beta 1$ has been shown to play an important 
role in the invasiveness, metastasis formation, and drug resistance of cancer cells [26]. As integrins bind to the ECM, they aggregate and direct the formation of a cytoskeletal and signaling complex that results in the assembly of actin filaments [19]. Integrin binding to ECM protein or integrin crosslinking increases tyrosine phosphorylation of focal adhesion kinase (FAK) [20].

FAK, a tyrosine kinase, is a peripheral membrane protein and interact with integrin. FAK is believed to role as a central molecule in integrin-mediated signaling. It is one of the core adhesion proteins involved in cellular motility and protection against apoptosis [6,21]. FAK resides at sites of integrin clustering, so called the focal adhesions, that are prominent in cells that are grown in tissue culture. FAK carries out protein-protein interaction adaptor functions at sites of cell attachment to the ECM, thereby contributing to focal-adhesion 'scaffolding', and also transmits adhesion-dependent and growth-factor-dependent signals into the cell interior. FAK influences the dynamic regulation of integrin-associated adhesions, and the actin cytoskeleton that is tethered there, through diverse molecular interactions [16].

Actin remodeling is another crucial element of the cell-motility process. Adhesion dynamics are tightly linked to control of actin assembly and disassembly and FAK contributes to both, the latter usually by influencing RhO-GTPase pathways [5]. Integrins transduce signals by associating with adapter proteins that connect to the transmembrane growth factor receptors, cytoplasmic kinases, and cytoskeleton. The binding of integrin-ECM protein initiates by integrin clustering in the plane of cell membrane, promoting the assembly of cytoskeletal actin [23]. Actin reorganization stimulates the further association of integrin to large multi-protein aggregates, stimulating cell-matrix adhesion that allows, through cytoskeletal actin anchoring, peculiar cell and nuclear shape changes. These bio-molecular effects are necessary during cell cycle regulation/progression, ultimately directing the cell to proliferate, differentiate and/or die $[8,27]$. Adhesion and cytoskeletal proteins provide the basic infrastructure in maintaining the cell shape and function. Alteration of actin remodeling not only plays an important role in regulating the morphologic and phenotypic events of a malignant cell but also provides a potential target for anticancer drug development. In the present study, to investigate the cytotoxic effect spm the expression of adhesion and cytoskeletal proteins including the integrin $\beta 1$, FAK, and actin was studied in MCF-7 cells by Western blotting and confocal laser scanning microscopy.
Materials and Methods

\section{Chemicals}

3-[4,5-dimethylthiazol-2-yl]-2,5-diphenyl tetrazolipM (MTT), spd (N-[3-aminopropyl]-1,4-butanediamine), spm ( $\mathrm{N} \mathrm{N}^{\prime}-$ bis[3-aminopropyl]-1,4-butanediamine), 2-\{[3-(trifluoro methyl)phenyl]amino\} benzoic acid (Fluofenamic acid), trypan blue, Fluo-3/AM, propidiuM iodide (PI), ribonuclease A, Dulbecco's modified Eagle's mediuM (DMEM, with L-glutamine and 1,000 mg/l Glucose) were purchased from Sigma Chemical Co (St. Louis, MO, USA). Fetal bovine serum (FBS) was purchased from GIBCO (New York, USA). All other chemicals were purchased from standard commercial sources.

\section{Cell culture}

The MCF-7 human breast carcinoma cell line was obtained from the American Type Culture Collection (ATCC, Rockville, MD), and maintained in DMEM containing phenol red with 10,000 units/ $\mathrm{ml}$ penicillin $\mathrm{G}, 10 \mathrm{mg} / \mathrm{ml}$ streptomycin, and 10\% heat-inactivation FBS in a humidified atmosphere of $95 \%$ air; $5 \% \mathrm{CO}_{2}$ at $37^{\circ} \mathrm{C}$. Culture media were changed every 2 or 3 days. Cells were harvested using trypsin-EDTA and subcultured at weekly intervals.

\section{Measurement of cell viability}

Cell viability were determined by using microculture tetrazolium technique (MTT) and trypan blue. The MTT assay is a quantitative colorimetric assay for mammalian cell survival and proliferation, based on the ability of live cells to utilize a pale yellow substrate, and its subsequent modification into a dark blue formazan product by these cells. MCF-7 cells were plated at $5 \times 10^{4}$ cells $/ \mathrm{ml}$ in 48 wells in phenol red-free DMEM ( $2 \%$ DCC-serum). Cells were allowed to adhere $24 \mathrm{hrs}$, then incubated for additional 1, 2, and 3 days in different drug concentrations. Details for MTT assay are described in elsewhere [14]. Trypan blue is a water-soluble dye used for the dye exclusion test for cell viability to distinguish between viable and nonviable cells by seeping into nonviable cells with damaged plasma membranes causing them to appear blue. MCF-7 cells were plated onto 6-well plates at approxi-mately $2 \times 10^{5}$ cells per well and incubated for $24 \mathrm{hrs}$. After the cells were treated with spm at various concentrations, cells were harvested by trypsinization and resuspended in $0.4 \%$ trypan blue solution for $5 \mathrm{~min}$. An aliquot of the cell suspension was taken in a hemocy- 
tometer, observed under phase contrast microscope to determine cell viability.

\section{Assessment of morphology}

The cells were either attached on slide glass by cytospin centrifugation for $5 \mathrm{~min}$ at $900 \mathrm{rpm}$ using cellspin (Hanil). The cells were then fixed with $4 \%$ paraformaldehyde (Sigma, MO, USA) at room temperature for $20 \mathrm{~min}$. Fixed cells were washed three times with PBS for $10 \mathrm{~min}$ and incubated with $0.2 \%$ Triton X-100 for 15 min. After three washes with PBS, the cells were incubated with an appropriate primary antibody in $1 \%$ bovine serum albumin (BSA) at room temperature for $2 \mathrm{hrs}$. For secondary reaction, the cells were incubated with an appropriate FITC -conjugated secondary antibody at room temperature for $2 \mathrm{hrs}$. The cells were incubated with Texas red phalloidin at room temperature for 2 hrs. Finally, the cells were mounted on glass slides and observed under Confocal microscope (LSM510, Carl Zeiss, Germany).

\section{Flow cytometric analysis}

Cells were harvested, fixed with 95\% ethanol for $24 \mathrm{hrs,}$ incubated with $0.05 \mathrm{mg} / \mathrm{ml} \mathrm{PI}$ and $1 \mu \mathrm{g} / \mathrm{ml}$ RNase A at $37^{\circ} \mathrm{C}$ for $1 \mathrm{hr}$, and analyzed by flow cytometry, using an Epics $\mathrm{XL}$ and analysis software (EXPO32 ${ }^{\mathrm{TM}}$; Beckman Coulter, MI, USA). The cells belonging to the sub-G1 population were considered to be apoptotic cells; the percentage of each phase of the cell cycle was determined.

\section{Western blot analysis}

The cells treated with spm were harvested and lysed in lysis buffer $(10 \mathrm{mM}$ Tris/HCl, $\mathrm{pH}$ 7.4, $150 \mathrm{mM}$ sodium chloride $(\mathrm{NaCl}), 5$ mM EDTA, $\mathrm{pH}$ 8.0, with 1\%Triton X-100, 0.01 $\mathrm{mg} / \mathrm{mL}$ aprotinin and $0.04 \mathrm{mg} / \mathrm{ml}$ phenylmethyl-sulfonylfluoride (PMSF)). Equivalent amount of protein $(20 \mu \mathrm{g})$ from each sample was subjected to electrophoresis using 10-12\% sodium dedocyl sulfate polyacrylamide gel electrophoresis (SDS-PAGE). Total proteins were estimated by the method of Bradford assay. After SDS-PAGE proteins were transferred onto nitrocellulose paper (Bio-Rad) in a Bio-Rad electroblotting device. Ponseau S staining of transferred membranes was used to monitor loading equivalence and transfer efficiency. Nitrocellulose matrices were preblocked with 5\% skim milk in TBST (Tris buffer saline, pH 7.4 containing $0.1 \%$ Tween-20) buffer for $1 \mathrm{~h}$ at room temperature. Following TBST washing preblocked matrices was $4^{\circ} \mathrm{C}$ overnight with various primary antibodies, and then with secondary antibody. The immune-complexes were detected using the ECL (enhanced chemiluminescence) detection kit (Amersham, USA).

\section{Statistical analysis}

All experiments were carried out at least in triplicate. Results were expressed as mean \pm SEM. Statistical significances between the control and the treatment group were determined by one-way analysis of variance and then followed by the Student $\mathrm{T}$ test. In all cases, a $p$ value of less than 0.05 was considered statistically significant.

\section{Results}

\section{Effect of polyamine on cell viability}

The effect of polyamine on the viability of MCF-7 cells was examined using the MTT staining method. In order to determine the effect of polyamines on MCF-7 cell viability, cells were treated for 1 3 days with spm and spd. As shown in Fig. 1, spd did not have any significant effect on cell viability. However, when cells were treated for 3 days with
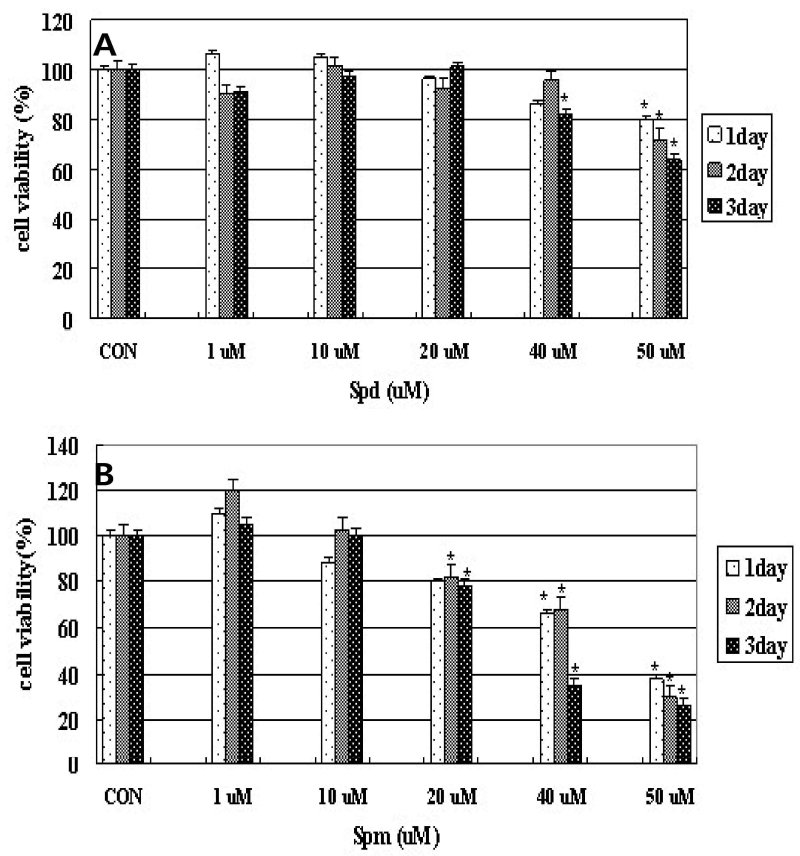

Fig. 1. Effect of spd and spm on cell viability in MCF-7 cells. Cells were plated in 48 -wells at $5 \times 10^{4}$ cells $/ 1 \mathrm{ml}$ in DMEM. Cells treated with (A) spd $(1-50 \mu \mathrm{M})$ and (B) spm $(1-50 \mu \mathrm{M})$ for 3 days, and then viability was measured by the MTT assay. Statistical analysis was performed by the student's test. ${ }^{*} p<0.05$ vs. control 
1-50 $\mu \mathrm{M}$ of spm, cell viability decreased in a dose- and time-dependent manner as shown in Fig. 1B. At the lower concentration (under $10 \mu \mathrm{M}$ ), spm did not affect cell viability. But rather cell viability slightly increased to $120 \%$ of the control at $1 \mu \mathrm{M}$ spm treated for 2 days. Cells treated with $20 \mu \mathrm{M}$ spm showed about $80 \%$ viability after 3 days incubation compared to the control. However, at $40 \mu \mathrm{M} \mathrm{spm}$ treated, cell viability dropped to $37 \%$ of the control on 3days incubation. At $50 \mu \mathrm{M}$ spm cell viability dropped below 37\% of the control in 3 days incubation. Put, which is the precursor of spd and spm, did not give any noticeable effect on cell viability (data not shown).

Effects of spm on MCF-7 viability assessed with trypan blue

MCF-7 viability was also assessed using trypan blue dye exclusion assay after $24 \mathrm{hrs}$ of treatment with spm. It is reported that live healthy cells will exclude the dye and appear opaque, while the dead and very weak cells take the dye and stain blue when observed under a light microscope. The results clearly showed that cell viability started to decrease within 24 hrs treatment of spm in a dose-dependent manner as shown in Fig. 2. Cells treated with $50 \mu \mathrm{M}$ spm showed about $38 \%$ viability for 1 day incubation compared to the control in the MTT assay. But in the trypan blue assay, cells treated with $50 \mu \mathrm{M}$ spm showed about $62 \%$ viability for 1 day incubation.

Effects of spm on MCF-7 viability assessed by flow cytometry

To explore more clearly the viability inhibitory effect of spm in MCF-7 cells, the cell cycle was analyzed using propidium iodide staining and flow cytometry. The results showed a typical sub-G1 arrest pattern in spm treated cells. As shown in Fig. 3, sub-G1 populations increased in a dose-dependent manner by spm treatment. At $50 \mu \mathrm{M}$ spm, cell death reached $51.2 \%$. The flow cytometric analysis demonstrated that cells appear to accumulate at sub-G1 phases following spm treatment, with a concomitant decrease in the percentage of cells in the S and G2-M phase when compared to the control. These results suggest that spm causes the induction and accumulation of MCF-7 cells at sub-G1phase, resulting cell death subsequently.

\section{Morphological changes of spm treated cells}

To study the cytotoxic effect of spm in detail, the early effect on cell morphology was observed using phase-contrast microscope. A high concentration of spm treatment rendered morphological changes in MCF-7 cells as shown in Fig. 4. Cells started shrinking and rounding approximately $2 \mathrm{hrs}$ after treatment. After $12 \mathrm{hrs}$, cells were considerably detached from the culture dish surface, and after $24 \mathrm{hrs}$, most of the cells were detached and also lost cell-cell attachment. Spm induced morphological changes as well as inhibition of adhesion, migration and spreading.

Effect of spm on the expression of integrin $\beta 1$, FAK, and actin proteins

The change in protein level of FAK, Integrin $\beta 1$, and actin were analyzed by Western blotting. As shown in Fig. 5, when cells were treated with spm for $24 \mathrm{hrs,} \mathrm{FAK} \mathrm{expression}$ level decreased drastically. However, integrin $\beta 1$ expression

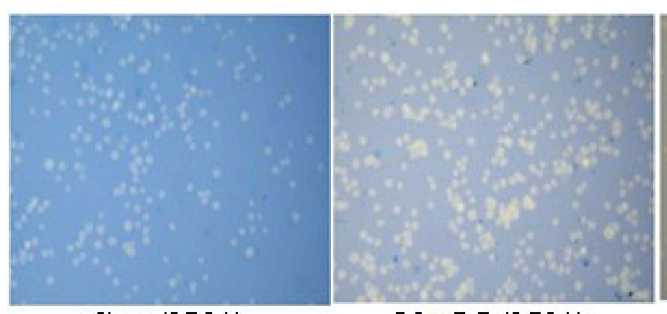

Con $(98 \%)$

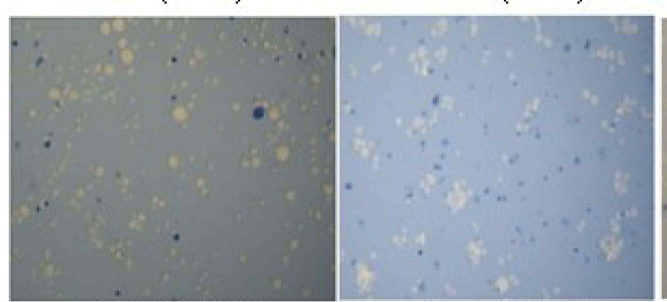

$30 \mathrm{uM}(78 \%)$
$40 \mathrm{uM}(72 \%)$

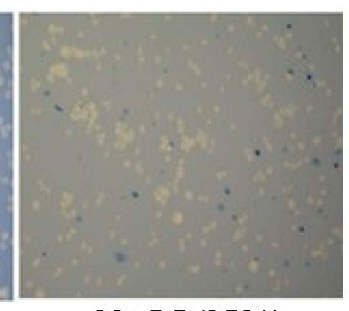

$20 \mathrm{uM}(95 \%)$

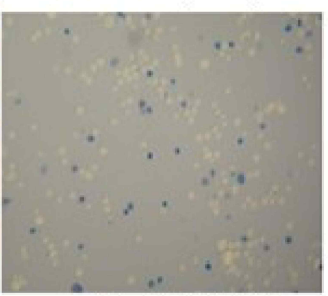

$50 \mathrm{uM}(62 \%)$
Fig. 2. Cell viability after $24 \mathrm{hrs}$ of spm treatment (\%: percent of live cells). Cells were plated in 6-wells at $2 \times 10^{5}$ cells $/ 2 \mathrm{ml}$ in DMEM and incubated for $24 \mathrm{hrs}$. After the cells were treated with spm $(10-50 \mu \mathrm{M})$ for $24 \mathrm{hrs}$, viability was measured by the trypan blue assay. Data shown are representative of three independent experiments. 


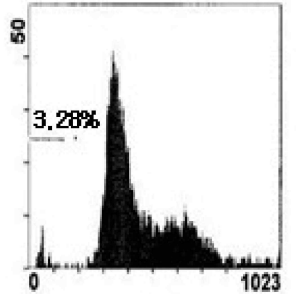

Con

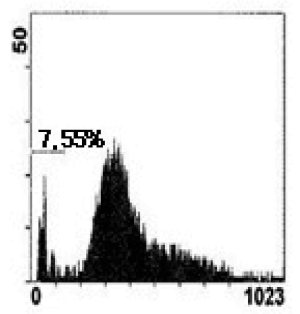

$30 \mathrm{uM}$

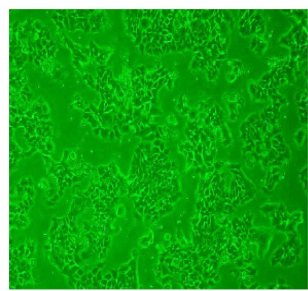

Con

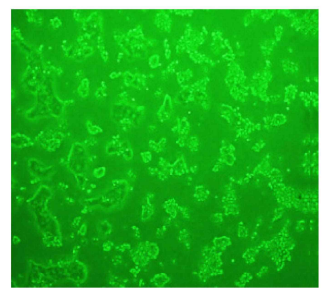

6 hrs

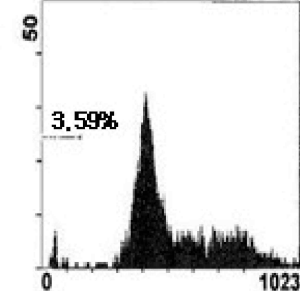

$10 \mathrm{WM}$

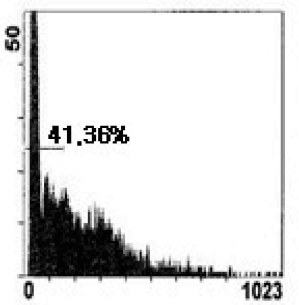

$40 \mathrm{uM}$

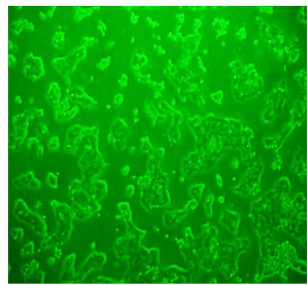

2 hrs

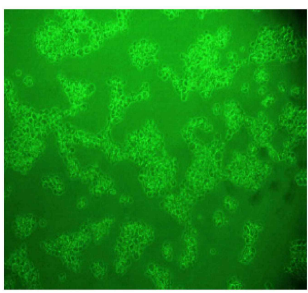

12 hrs

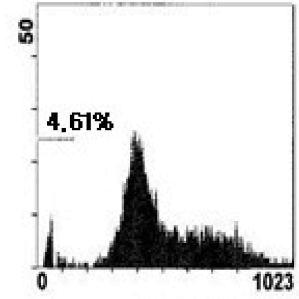

$20 \mathrm{uM}$

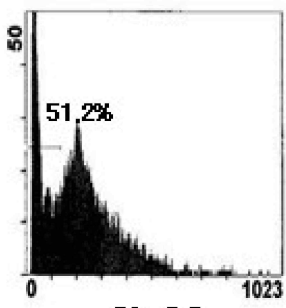

$50 \mathrm{uM}$

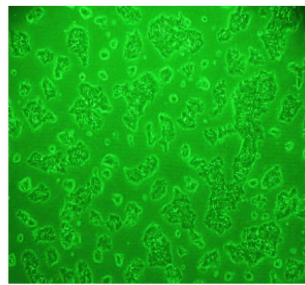

4 hrs

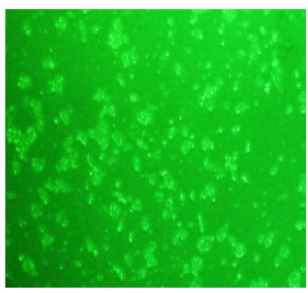

24 hrs
Fig. 3. Identification of cell death by sub-G1 analysis (\%: percent of dead cells). Cells were incubated for $24 \mathrm{hrs}$ in 6-wells at $2 \times 10^{5}$ cells $/ 2 \mathrm{ml}$ in DMEM. After cells were treated with spm $(10-50 \mu \mathrm{M})$ for 24 hrs, viability was measured by flow cytometry. Data shown are representative of three independent experiments. levels increased slightly in $10 \mu \mathrm{M}$ spm, then slightly decreased at higher concentrations. Actin levels also diminished in a dose-dependent manner compared to the control.

$$
\text { Immunofluorescence analysis of FAK, integrin } \beta 1 \text {, }
$$
and actin

The alteration in the cellular distribution of cytoskeletal proteins was checked by confocal microscopy. As shown in Fig. 6, actin and integrin $\beta 1$ appeared evenly expressed in the plasma membrane of the untreated cells, mainly located at focal contacts homogeneously distributed along the membrane of spread cells. Actin, which appeared under the plasma membrane of the cell in control, was decreased in a dose-dependent manner with spm treatment. Integrin $\beta 1$ al- so decreased in spm treatment. Besides that level change, some alterations of integrin $\beta 1$ distribution in the plasma membrane were noticed. Integrin $\beta 1$, mainly found in the focal point of the plasma membrane in the untreated control, dispersed through the entire plasma membrane in spm treatment. FAK levels also decreased by spm treatment. However, FAK intracellular distribution was different from that of actin and integrin $\beta 1$. It seemed like FAK was evenly distributed under the plasma membrane in the untreated control. However, at $10 \mu \mathrm{M}$ spm FAK seemed to move toward the cell nucleus. The expression of FAK was almost completely knocked out at $40 \mu \mathrm{M}$ spm even though actin was still under the membrane focal point as shown in the merged picture of Fig. 6 . 

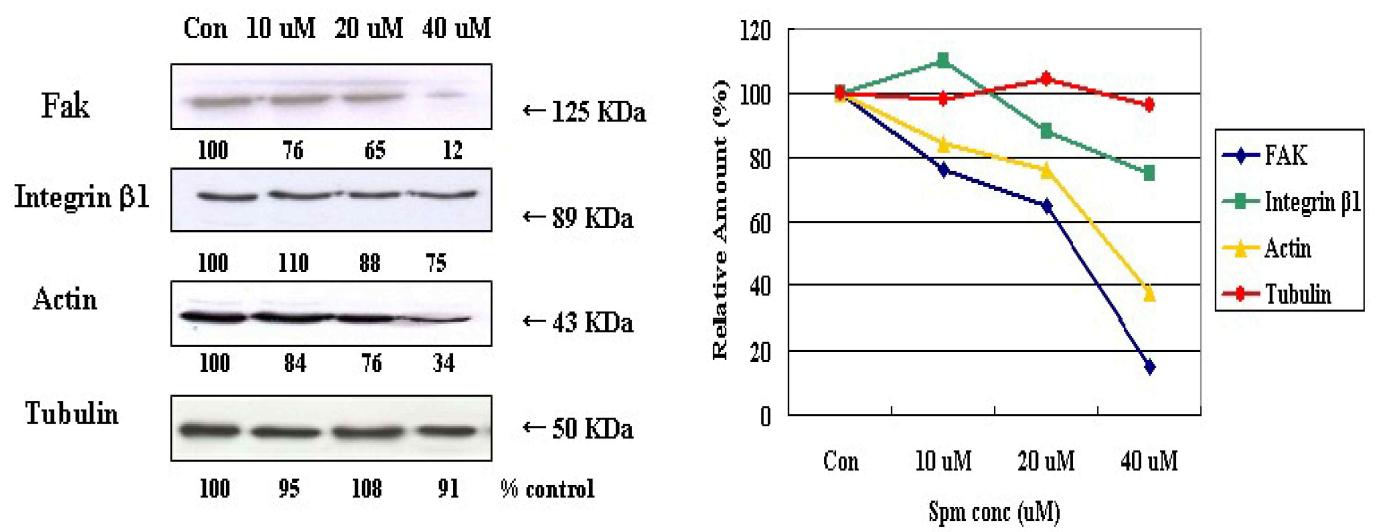

Fig. 5. Western blotting showing the effects of spm on the FAK, integrin $\beta 1$, actin protein levels. Cells were treated with spm $(10-40 \mu \mathrm{M})$ for $24 \mathrm{hrs}$. Equal amounts of proteins were separated by SDS-PAGE, and western blot analysis was performed using FAK-, integrin $\beta 1-$, and actin-specific antibodies. Data shown are representative of three independent experiments.
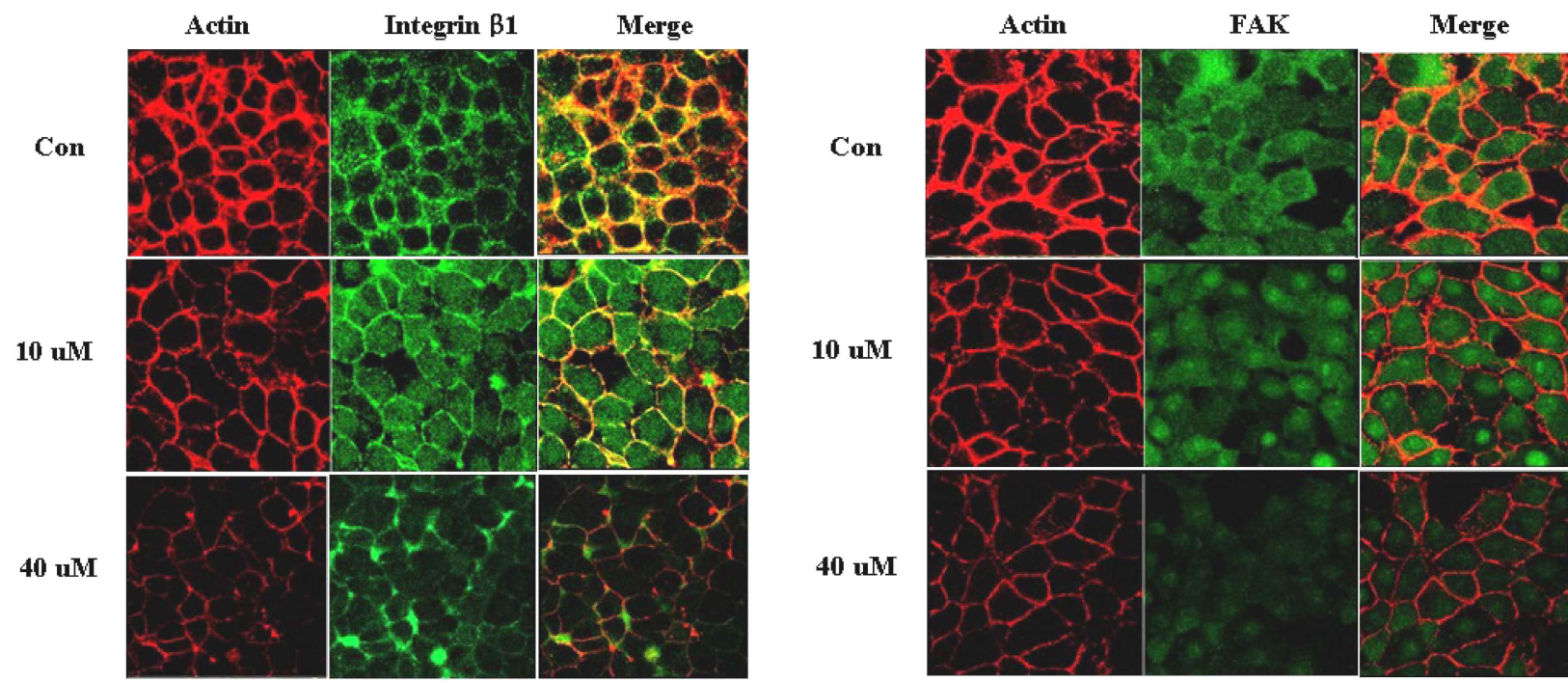

Fig. 6. Immunofluorescence analysis of actin, integrin $\beta 1$, and FAK. Cells were treated with spm $(10 \mu \mathrm{M}$ and $40 \mu \mathrm{M})$ in complete medium on glass coverslips for $24 \mathrm{hrs}$, then fixed and permeabilized. Co-localization of actin and integrin $\beta 1$ was analyzed by confocal microscopy of the cells subsequently incubated with anti-integrin $\beta 1$ (1:100) and anti-mouse IgG FITC-conjugated secondary antibody (1:100), followed by incubation with the phalloidin (1:100). Co-localization of FAK and actin was analyzed by confocal microscopy of the cells subsequently incubated with anti-Fak (1:100) and anti-rabbit IgG FITC-conjugated secondary antibody (1:100), followed by incubation with the phalloidin (1:100). Data shown are representative of three independent experiments.

\section{Discussion}

Polyamines are known to be essential and play multifunctional roles in cell viability, growth, proliferation and differentiation [23]. Polyamines have also been known to be implicated in cell death. It appears that polyamines are bivalent regulators of cellular functions, promoting proliferation or cell death depending on the cell type and on environmental signals [12,18]. Among them, spm was most effective in in- hibiting cancer cell growth The cytotoxicity of spm has been recognized for many years. Also, the recent study examines that polyamine depletion inhibited migration [15] and delayed cell attachment to ECM proteins by disrupting the cytoskeleton [22]. Previous studies have shown that increased spm concentrations in tumor tissues are correlated with cancer progression and that restriction of polyamine availability inhibits tumor growth [13]. However, the present results show that polyamines, especially spm, suppressed MCF-7 
cell viability and also decreased the expression of several cytoskeletal proteins. The results showed that spm caused a time- and dose-dependent cell viability decrease. In the MTT assay of MCF-7 cells treated with spm, cell viability decreased rapidly. These results suggest that disturbance in intracellular spm level is related to cell death. The above results were confirmed again by the trypan blue assay. The trypan blue assay suggested that spm induced cell detachment before cell death through the disturbance of cytoskeletal proteins in MCF-7 cells. Flow cytometric analysis confirmed the above results. Flow cytometric analysis showed that significant cell death occurs in the cells treated with spm. At $50 \mu \mathrm{M}$ spm, cell death reached $51.2 \%$. The results demonstrated that cells accumulated at sub-G1 phases following spm treatment, with a concomitant decrease in the percentage of cells in the $\mathrm{S}$ and G2-M phase, compared to the control. It is known that the appearance of surface rounding and blebbing has been linked with alterations of cytoskeletal structure and function. Spm treatment rendered morphological changes of MCF-7 cells. Cell started shrinking and rounding approximately $2 \mathrm{hrs}$ after the treatment. After $12 \mathrm{hrs}$ of spm treatment, cells were considerably detached from the culture dish surface, and after $24 \mathrm{hrs,} \mathrm{most} \mathrm{of} \mathrm{the}$ cells were detached and lost cell-cell attachment. These results indicate that the treatment of spm in MCF-7 cells led to morphological changes suggesting an aberrant function of cytoskeleton proteins. The shape change may be due to significant alterations in the levels of cytoskeletal proteins, suggesting that integrin $\beta 1$ and other cytoskeleton-bound proteins may be early targets of spm.

Cytoskeletal linkages also enable integrins to regulate cell shape and gene expression, mediating cell adhesion, spreading and migration of cells on ECM; all these processes are dependent on cytoskeletal actin [3]. Integins are physically linked to actin cytoskeleton to mediate the focal adhesions, which comprise large protein complexes containing both cytoskeleton and signaling through FAK. It has been proposed that FAK plays a critical role in cell migration as well as in the regulation of cell survival and cell cycle progression [17]. FAK carries out protein - protein-interaction adaptor functions at sites of cell attachment to the ECM [16]. Both in Western blotting and confocal microscopy, FAK was affected most severely by spm treatment as shown in the present work. FAK seemed to move toward the cell nucleus. Actin also showed level decrease, but without any cellular distribution in spm treatment. The membrane distribution pattern of integrin was mainly in the focal adhesion point in the control, but the spm treatment induced big change to even membrane distribution. Compared to the level change of actin and FAK, integrin level did not show a drastic decrease.

According to the results of the present work, spm affects especially FAK, which influence the actin and integrin modulation. FAK rapidly disappeared with spm treatment in MCF-7 cells and cell adhesion capacity was decreased. Therefore, the cytotoxic effect of spm seemed to be carried out by inducing the loss of cell attachment to the ECM, which is anoikis. Anoikis, a subset of apoptosis, is triggered by inadequate or inappropriate cell-matrix contacts [9]. Many kinase/phosphatase signaling molecules, including raf and phosphoinositide-3-kinase are known to be involved in the regulation of anoikis. Since bcl-2 expression levels are regulated by the above signaling molecules, the modulation of cytoskeletal proteins induced by spm might be correlated to the upstream event of apoptosis.

The level change of anti-apoptotic Bcl-2 and pro-apoptotic Bax proteins by spm treatment in MCF-7 cell was already reported in previous paper. Instead of caspase-3, caspase-7 played a key role in the downstream event of apotosis [14].

The control of FAK could be to the clinical application for the prevention of metastasis. FAK is often over expressed in cancer cells [24]. FAK is a multifunctional protein that plays a critical role in the integrin signaling [21] as well as a key molecule in tumor cell metastasis [16]. Therefore, understanding of the adhesion and cytoskeletal protein modulation can be critical for the control of cancer.

\section{Acknowledgement}

This work was supported for two years by Pusan National University Research Grant.

\section{References}

1. Arancia, G., A. Calcabrini, M. Marra, P. Crateri, M. Artico, A. Martone, F. Martelli, and E. Agostinelli. 2004. Mitochondrial alterations induced by serum amine oxidase and spermine on human multidrug resistant tumor cells. Amino Acids 26, 273-282.

2. Averill-Bates, D. A., Q. Ke, A. Tanel, J. Roy, G. Fortier, and E. Agostinelli. 2008. Mechanism of cell death induced by spermine and amine oxidase in mouse melanoma cells. Int. J. Oncol. 32, 79-88.

3. Calderwood, D. A., S. J. Shattil, and M. H. Ginsberg. 2000. 
Integrins and actin filaments: Reciprocal regulation of cell adhesion and signalling. J. Biol. Chem 275, 22607-22610.

4. Carragher, N. O. and M. C. Frame. 2004. Focal adhesion and actin dynamics: a place where kinases and proteases meet to promote invasion. Trends Cell Biol. 14, 241-249

5. Chen, B. H., J. T. Tzen, A. R. Bresnickand, and H. C. Chen. 2002. Roles of Rho-associated kinase and myosin light chain kinase in morphological and migratory defects of focal adhesion kinase-null cells. J. Biol. Chem 277, 33857-33863.

6. Crowe, D. L and A. Ohannessian. 2004. Recruitment of focal adhesion kinase and paxillin to $\beta 1$ integrin promotes cancer cell migration via mitogen activated protein kinase activation. BMC. Cancer 4, 18-23.

7. Fidler, I. J. 1991. Cancer metastasis. Br. Med Bull. 47, 157-177.

8. Frisch, S. M. and E. Ruoslahti. 1997. Integrins and anoikis. Curr. Opin. Cell Biol. 9, 701-706.

9. Frisch, S. M. and R. A. Screaton. 2001. Anoikis mechanisms. Curr. Opin. Cell Biol. 13, 555-562.

10. Garcia, A. J. and D. Boettiger. 1999. Integrin-fibronectin interactions at the cell-material interface: initial integrin binding and signaling. Biomaterials 20, 2427-2433.

11. Giancotti, F. G. and E. Ruoslahti.1999. Integrin signaling. Science 285, 1028-1032.

12. Han, L. C., C. Jiang, H. Li, W. Zhang, Y. Zhao, L. Zhang, Y. Zhang, W. Zhao, and B. Yang. 2007. Effects of polyamines on apoptosis induced by simulated ischemia/reperfusion injury in cultured neonatal rat cardiomyocytes. Cell Biol. Int. 31, 1345-1352.

13. Holst, C. M., B. Frydman, L. J. Marton, and S. M. Oredsson. 2006. Differential polyamine analogue effects in four human breast cancer cell lines. Toxicology 223, 71-81.

14. Jang, E. S. and B. G. Kim. 2008. Mechanism of Apoptosis induced by spemine in MCF-7 breast cancer cells. Korean J. Life Sci. 18, 1177-1185.

15. McCormack, S. A., J. Y. Wang, and L. R. Johnson. 1994. Polyamine deficiency causes reorganization of F-actin and tropomyosin in IEC-6 cells. Am J. Physiol. Cell Physiol. 267, C715-C722.

16. McLean, G. W., N. O. Carragher, E. Avizienyte, E. J. Evans, V. G. Brunton, and M. C. Frame. 2005. The role of focal adhesion kinase in cancer-a new therapeutic opportunity. Nat. Rev. Cancer 7, 505-515.
17. Mitra, S. K. and D. D. Schlaepfer. 2006. Integrin-regulated FAK-Src signaling in normal and cancer cells. Curr. Opin. Cell Biol. 18, 516-523.

18. Pignatti, C., B. Tantini, C. Stefanelli, and F. Flamigni. 2004. Signal transduction pathways linking polyamines to apoptosis. Amino Acids 27, 359-365.

19. Ray, R. M., M. J. Viar, A. Shirley, A. McCormack, and L. R. Johnson. 2001. Focal adhesion kinase signaling is decreased in polyamine-depleted IEC-6 cells. Am J. Physiol. Cell Physiol. 281, C475-478.

20. Richardson, A., R. K. Malik, J. H. Hildebrand, and J. T. Parsons. 1997. Inhibition of cell spreading by expression of the C-terminal domain of focal adhesion kinase (FAK) is rescued by coexpression of src or catalytically inactive FAK: a role for paxillin tyrosine phosphorylation. $\mathrm{Mol}$. Cell Biol. 17 6906-6914.

21. Sanders, M. A. and M. D. Basson. 2000. Collagen IV-dependent ERK activation in huMan Caco-2 intestinal epithelial cells requires focal adhesion kinase. J. Biol. Chem 2000; 275, 38040-38047.

22. Santos, M. F., M. J. Viar, S. A. McCormack, and L. R. Johnson. 1997. Polyamines are important for attachment of IEC-6 cells to extracellular matrix. Am J. Physiol. Gastrointest Liver Physiol. 273, G175-G183.

23. Schlaepfer, D. D., C. R. Hauch, and D. J. Sieg. 1999. Signaling through focal adhesion kinase. Prog. Biophys. Mol. Biol. 71, 435-478.

24. Thamilselvan, V. and M. D. Basson. 2004. Pressure activates colon cancer cell adhesion by inside-out focal adhesion complex and actin cytoskeletal signaling. Gastroenterology 126, 8-18.

25. Thomas, T. and T. J. Thomas. 2001. Polyamines in cell growth and cell death: molecular mechanisms and therapeutic applications. Cell Mol. Life Sci. 58, 244-258.

26. van Golen, C. M., M. E. Soules, A. R. GrauMan, and E. L. Feldman. 2003. N-Myc overexpression leads to decreased $\beta 1$ integrin expression and increased apoptosis in hum an neuroblastoma cells. Oncogene 22, 2664-2673.

27. Warry, K. K., A. Mariotti, C. Zurzolo, and F. G. Giancotti. 1998. A requirement for caveolin-1 and associated kinase Fyn in integrin signaling and anchorage-dependent cell growth. Cell 94, 625-634. 


\section{초록 : MCF-7 세포에서 spermine에 의한 부착단백질 Integrin $\beta 1$ 과 FAK, 세포골격 단백질 actin의} 조절

지혜진 · 김병기*

(부산대학교 자연과학대학 생명과학과)

Polyamine은 모든 세포의 성장과 분화에 필수적인 요소지만 그 기작은 아직 정확하게 밝혀져 있지 않다. 본 논문에서는 MCF-7세포에서 spm의 세포독성 기작을 연구하였다. MTT assay 결과 저농도의 spm $(<10 \mu \mathrm{M})$ 처리 시 cell viability가 증가하는 반면 고농도의 spm 처리시 처리 시간과 처리 농도에 의존적으로 감소되었으며, 이는 고농도의 spm이 MCF-7 cell에 cytotoxic한 효과를 가지고 있는 것으로 사료된다. Cell cycle 분석 결과 spm 농도 에 의존적으로 sub-G1 단계의 세포 양이 증가하는 것으로 나타났으며, 이는 spm이 세포분열을 억제함으로써 세 포사를 유발하는 것으로 생각된다. 또한 고농도의 spm 처리 후 2시간이 지나자 cell 표면이 움츠려 들며 rounding 되기 시작하여 하루가 지난 후 거의 모든 cello이 culture dish 에서 떨어진 것을 관찰할 수 있었다. 이는 spm이 세포부착에 관여하여 세포사를 유발하는 것이라 생각되며, 세포부착을 조절하는 Integrin $\beta 1$ 은 저농도의 spm에 선 별다른 차이를 보이지 않다가 농도가 높아질수록 조금씩 감소하였으며, cytoskeletal protein인 actin은 농도의 존적으로 감소하였다. 반면 adhesion protein인 FAK는 저농도의 spm 처리시에도 급격히 감소하였다. 이는 spm 이 adhesion 및 cytoskeletal proteins의 발현을 억제하는 것으로 보이며, 특히 Integrin $\beta 1$ 과 actin에 비해 FAK에 더 많은 영향을 끼치는 것으로 사료된다. 단백질들의 세포막상의 분포에 관한 연구에서, membrane 상에 위치 하던 Integrin $\beta 1$ 은 $10 \mu \mathrm{M}$ 의 spm 처리시 세포 내로 약간의 위치변동이 일어났으나 그 양에는 크게 차이가 없었 으며, 반면에 actin은 위치상엔 큰 변화가 일어나지는 않았지만 농도에 따라 크게 감소하는 것으로 나타났다. 세 포이동과 형태조절에서 중추적인 역할을 하는 FAK는 세포막 안쪽에 위치하고 있다가 spm 처리시 세포 가운데 로 이동하는 모습이 관찰되었으며 그 양도 크게 감소하였다. 이상의 실험에서 세포 내 spm의 변화는 MCF-7 cell 의 adhesion protein인 Integrin $\beta 1$ 과 FAK, 그리고 cytoskeletal protein인 actin의 발현을 조절하여 cell attachment를 억제함으로써 세포분열과 생장을 억제하는 것으로 분석된다. 